\title{
清酒の需要の予测 (2)
}

\author{
本稿では清酒需要の予測式とその計算に必要な諸係数を示し, それか \\ ら導かれる予測需要量が全国規模および各都道府県別とに分けて示され \\ ている。数多くの回帰式について電算機を駆使されての結果, 清酒の需 \\ 要が時間を変数とする簡単な関数で示し得るということは興味深い。
}

\section{黒 沢 一 清/東京工業大学}

\section{4. 全国レベルでの予測について}

\section{（1）市場構造についての主な結論}

私共はすでに本誌上で，わが国の酒類市場の在り方と その変貌について，清酒を中心としながらかなり詳細に 検討してきたので,ここでは值接に, 清酒の需要予测の作 業結果を要約して述べたいと思う。わが国の戦後の酒類 需要は, 一般的にみて戦前に比べ質的にも量的にも高い 水準に逞している。この点では清酒るまた例外ではない のである。乙かし, 周知のように生活様式は大变欧米化 してきて和り，そしてとくにその影響は若い世代に強 い。こうしたことから，これまで酒類世界の王座を占め てきた游酒の地位は急速に低下して扮り，反面ではとく にビールのシェアーの拡大は著しく,また最近では, 絶対 量ではまだ小量であるがウイスキーの成長率は極めて大 きい。もっともここ数年間の課税移出数量に占める清酒 の割合は大体 32〜3\% の水準で安定化の傾向がある。こ の背後には，郡部での清酒需翼があだかなり堅調で范る ことと, 都市部での特・1 級,なかんずく 1 級清酒を中心 とした激しいマーケッテイング活動があずかって抢り， 他方またビールの最近に叔ける伸び率の低下も影㖉して いると思われる。清酒の総消费量の $2 / 3$ 以上を占める 2 級清酒の需要が，すでに所得とマイナスの相関をもって おり，前にみたようにライフサイクル（寿命曲線）の上 では明らかに成熟後期の段階に入っている。そして清酒 全体としては，成熟期に属する県が全国の $3 / 4$ 以上を占 めているのである。こうした清酒の一般市場执よび酒類 市場に括ける劣勢は，生産者ならびに流通業者の各段階 の在庫量の增加にも現われている。これはとくに生産者 在庫の増加に执いて顕著であるが，それも本年に入って
からとくに著しい。この現象もまた, 清酒全体がライフサ イクルの成熟段階にさしかかっていることの反映である。

\section{（2）予測式の選択基準}

以上のような市場構造の吟味に基づいて私共は総計で 24 種の回㷌式を設定し FACOM-230-30 を用いて必要 な統計量を求めた。その結果について次のような選択基 準に従って検討を加え, 最終的に 3 種類の予測式を残し た。な特用いられたデータは昭和 33 年から 41 年の 9 年 間のものである。

(1) 推定値が実測值によく適合するょうな式であるこ と, とくに最近年度の実測値との偏差（ひらき）の小さ いものであること。

(2) 統訫学的吟味に, できるだけ耐光得るものである こと。

(3) 経済学の理論に反しないるのであること。

(4) 前項で述べたような私共の市場分析の結論に矛盾 しないものであること。

（3）決定された 3 種の予測式について モデル No. $8 \log D=A \log I+B \log M+C \log P+K$ ただし， $D$; 清酒の消費量 (単位 $; \mathrm{k} l$ )

$I$; 実質分配国民所得, 昭和 34 年洒格（単 位；億円）

$M ;$ 人口 (単位; 千人)

$P$; 清酒の相対佂格（清酒の平均価柗を一般 消費者物洒指数でデフレートしたもの) (単位; 円) $A, B, C, K$ はパラメーター

統計量は次のと叔り。

$$
\begin{array}{ll}
A=0.1071 & t_{A}=1.008 \\
B=0.603 \times 10 & t_{B}=6.83 \\
C=-0.823 & t_{C}=9.87
\end{array}
$$


$K=-0.224 \times 10^{2}$

$\bar{R}^{2}$ (自由度調整済みの重決定係数) $=0.998$ この式の意味は次のようである。この予測式は, 清酒需 要の変動のほぼ $99.8 \%$ までを説明することができる (重決定係数)。そしてその他の条件が一定のもとでは, 所得だけが $1 \%$ 増加すればそれに対応して清酒の需要量 は $0.107 \%$ だけ増加する。また同様に, 人口が $1 \%$ 増え れば 6\% だけ需要が増え, 清酒の一般物洒に対する相対 価格が 1\%だけ上がればそれに対応して $0.82 \%$ だけ需 要量が減少することを示している。

$$
\begin{aligned}
& \text { モデル No.11 } D=A T+B I+K \\
& \text { ただし， } D \text {; 清酒消費量 (単位 ; } \mathrm{k} l \text { ) } \\
& T \text {; 年度 (昭和 } 33 \text { 年 }=1 \text { ) } \\
& I \text {; 実質分配国民所得（単位; 億円） } \\
& \begin{array}{ll}
A=0.1537 \times 10^{6} & t_{A}=3.896 \\
B=-0.478 \times 10 & t_{B}=-1.547 \\
K=0.873 \times 10^{6} &
\end{array} \\
& \bar{R}^{2}=0.984
\end{aligned}
$$

この式では独立変数に所得と共に時間要素が組み込まれ ている。つまり清酒の需要が所得の変化によって影響さ れると同時に時間的にシフト(移行)するという考方に 立っている。この式について注目すべき点は需要が所得 に対してマイナスの回帰係数をもっていることである。

$$
\text { モデル No. } 23 \quad \log D=A T+B \log P+K
$$

記号の意味はすべて上と同じ。

$$
\begin{aligned}
A=0.306 \times 10^{-1} & t_{A}=24.67 \\
B=-0.781 & t_{B}=-11.10 \\
K=0.788 \times 10 & \\
\bar{R}^{2}=0.998 &
\end{aligned}
$$

\section{(4) 独立変数の予測式}

以上によって子测式が決定されたわけであるがこれを 用いて将来の需要量を予測するためには，各式の独立変 数のうちの時間以外の変数を新たに予測しなければなら ない。これが独立変数の予測式である。

1. 実質分配国民所得の予測式

$$
\log I_{t}=A \log I_{t-1}+K
$$

ただし， $I_{t} ; t$ 年度の昭和 34 年度価格表示の分配国 民所得 (単位 ; 億円)

$$
\begin{aligned}
& A, K \text { はパラメーター } \\
& A=0.908 \quad t_{A}=19.48 \\
& K=0.512 \\
& \bar{R}^{2}=0.979 \\
& \text { この式による } 2 \text { か年の予測值は次のと打り。 } \\
& \text { 昭和 } 43 \text { 年度 ; } 2.284 \times 10^{6} \text { 億円 } \\
& \text { 昭和 } 44 \text { 年度 ; } 2.392 \times 10^{6} \text { 億円 }
\end{aligned}
$$

2. 人口の予測式

$$
M=A T+K
$$

$M$; 人口 (単位 ; 千人)

$T$; 年度 (昭 $33=1)$

$A, K$ はパラメーター

$$
\begin{aligned}
A= & 0.950 \times 10^{3} \\
K= & 0.906 \times 10^{5} \\
& \bar{R}^{2}=0.998
\end{aligned}
$$

上式による予測值は次のと扣り。

昭和 43 年度 ; 101,027 千人

昭和 44 年度 ; 101,977 千人

3. 清酒の相対価格

各級別に売上数量をウエイトとする加重算術平均によ って平均価格を求める。

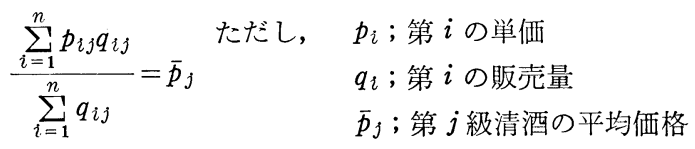

これをさらに各年度についての各級の消費量に占める割 合をウエイトとする加重算術平均をとって, 総体として の清酒の価格を求める。

$$
\sum_{j=1}^{3} \bar{p}_{j} S_{j}=\overline{\bar{p}}
$$

ただし， $\overline{\bar{p}}$; 総体としての清酒の平均価格

$$
\begin{gathered}
S_{j}=\frac{q_{j}}{\sum q_{j}} \text { で } j \text { は等級である。1 } 1 \text { が特級， } 2 \\
\text { が } 1 \text { 級， } 3 \text { が } 2 \text { 級である。 }
\end{gathered}
$$

以上のよ5にして求められた平均価格を昭和 34 年度を 100 とする一般消費者物価指数 (経企庁) でデフレート し，これを清酒の相対価格とした。昭和 43 年度の清酒 相対価格は, 43 年 7 月以降の清酒価格を 43 年 1 月から 4 月までの消費者物価指数でデフレートした。 44 年度の それは予測が困難なので 43 年度の值をそのまま用いた。 それは 431.2 円である。

\section{（5）清酒需要量の予測結果とその吟味}

各モデルによる将来 2 か年の計算結果は次のと拈りで ある。

私共の採用したモデル式は，まず統計学的観点からの 表 6 全国レベルの清酒吟味に対して比較的よく酎 需要の予測量

\begin{tabular}{r|l|l}
\hline $\begin{array}{r}\text { モデル } \\
\text { No. }\end{array}$ & 昭 43 年度 & 昭 44 年度 \\
\hline 8 & 141.4 万 $\mathrm{k} l$ & 150.3 万 k $l$ \\
11 & 147.3 & 157.3 \\
23 & 144.0 & 154.5 \\
\hline
\end{tabular}
学らる。多重共線関係を もつ式はモデル 8 だけであ る。また各独立変数のパラ メーターは著しく有意であ り, 各モデルの重決定係数

は甚だ高い値を示している。

清酒の需要予測作業に扣いて最も重要な点は, 清酒に ついては今日でもな㹉料米が統制されているために， われわれに与えられている市場資料は自由経済市場につ いて実現されたものではない，ということである。清酒 
の過去の実績は, いわば政府が配給した原料米の範囲だ けの清酒が供給されてきたものである。それは供給側の 挙動を示すものであって需要側の挙動を十分反映したも のとは必ずしもいえない。そこで私共は次のようにこの 問題に接近した。昭和 32 年までは上記の性格がとくに 濃厚であるので, 私共の需要関数の計測には 33 年以降 最新年度（41 年）までの資料を用いることにした。つま り 33 年頃以降では, 清酒市場の要求をできるだけ考慮 して原料米を供給する倾向が政府の政策のうちに現われ てきたことがその根拠である。第 2 は，消費者のサイド の資料による酒類市場の分析から清酒のライフサイクル の段階を判定し, 年々の供給量が潜在需要に対してどれ だけの供給率になっているかを達観的ではあるが推測し， この立場から予测関数のモデルを立て，またその結果を 吟味して 3 種頑の予測式を残すことにしたのである。

ここで清酒のライフサイクルが成熟段階に突入してい るという私共の想定を別の面から証明してみよう。それ は, ここ 8 年間の清酒の供給高が潜在的需要の何\%の供 給率になっていたかを测定してみることである。私共は この潜在需亚を次のようにして計算した。まず全国を7 つの文化圈汇分けた。そして各文化圈内の住民 1 人あた り清酒消费量の最高の県をその圈域の 1 人あたりの潜在 需要と考兄, これにその圈域内人口数を掛けてその地域 の総潜在需要とした。これをもってその地域の総消費量 を割ると供給率が得られる。これを昭和 33 年から 41 年までについて計算してグラフに描いたのが図 1 であ る。な拉六大都市圈については，各年の消費量を潜在需 要とみなした。つまり六大都市では 33 年以降供給率は つねに 100\% であったとみなしたのである。四1を一見 して明らかなよ 5 飞, 供給率は 37 年をピークとして以 降低下に向っている。これは, 前に指摘したように, 清 酒のライフサイクルが 36 年を変曲点として 37 年以降の 年平均成長率が低下し始めているといらことの別の表現 である。つまり，成長後期から成熟期に入ったために， マーヶットの容量の余裕が小さくなり，そのために供給 率をむしろ下げる方向に業界全体の意向が傾き，そして 政府もそれに歩調を揃えてきたといらことをこの曲線 は示している。

以上の分析からも明らかなように, 私共は清酒の需要

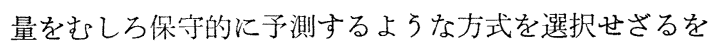
得ない。もちろん私共は清酒業界のマーケッテイング活 動が，こうした清酒市場の趨勢を変更せしめ得ないとは 思わない。しかし，以上の分析結果はこの業界にとって はかなり樶しい制約条件を示して蚂り，安易にこれを無 視することは許されないものであることは確かである。 な怙，ついでながら，消浆数量から課税移出数量への

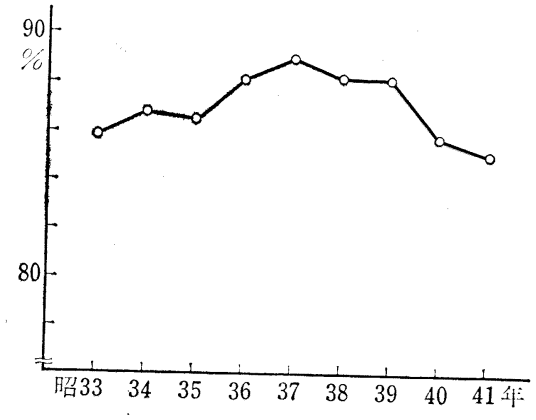

図 1 清酒の供給率

表 7 清酒の潜在需要を計測するための文化圈

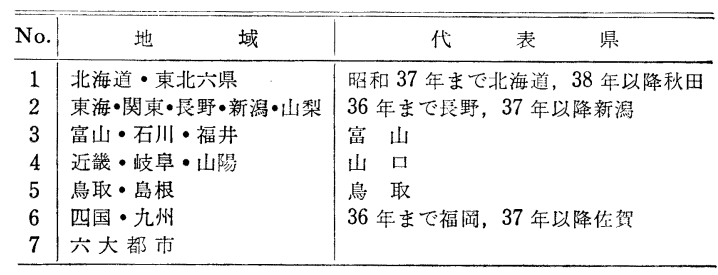

変換式を与えて招こなう。

(1) $Y_{t}=0.9095 X_{t}+147.8$

$X_{t} ; t$ 年度の消費量 (単位 $; \mathrm{k} l$ )

$Y_{t} ; t$ 锤造年度の課税移出数量 (単位; $\mathrm{k} l$ )

$$
R^{2}=0.997
$$

(2) $Y_{t}=1.00178 X_{t}+37.102$

$Y_{t}$ ならびに $X_{t}$ はいずれる財政年度

$$
R^{2}=0.949
$$

データは昭和 34 年から 42 年までである。上の (1) 式 による推定值は次のとおり。

表 8 課税移出数量の予測値

\begin{tabular}{c|c}
\hline モデル No. & 課税移出数量 (43 年度) \\
\hline 8 & 143.4 万 $\mathrm{k} l$ \\
11 & 148.9 \\
23 & 145.8 \\
\hline
\end{tabular}

\section{5. 都道府県別の清酒需要の予測}

\section{（1）都道府県別の清酒消費のパターン}

都道府県別の酒類別の消費水準执よびその構成の変化 についての私共の分析結果を要約すると表 9 のようであ る。

\section{（2）都道府県別の清酒の需要予測式}

表 9 を見て明らかなよらに地域のレベルでは清酒の消 費量は時間と著しく高い相関関係をもっている。私共は 各地域別にその地域の性格に適合した需要関数を測定し たが，ここでは各地域での予測作業に便利であるという 锥点から時間を独立変数とする予測式を記しておこう。 
表 9 都道府県別の清酒の清費のパターン

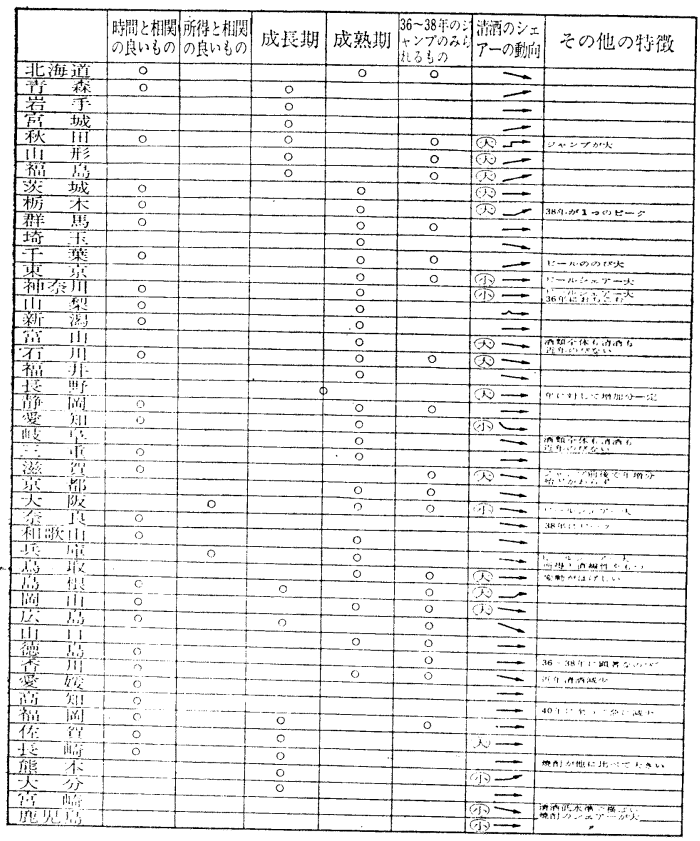

$\log D=A T+B$

共通の記号の意味恃次のと呿りである。

$D ; 1$ 人脑厄り清酒消党量 (単位; $l$ )

$T ;$ 昭和 $33=1$ とする年度の数

$\sigma$; 梆準偪差

”な揽児島と宫猗についてはこのような形式での安定 した予測式は得られなかった。それは，この高紧では乙 類しょらちゅ5の消䆓量が極端に多く, 清酒のシェアー が著しく小さくてその変動が大きいためで㐫っ。

な和秋田県については次の式を求めた。

$$
\log D=A T+B X+C
$$

ただし， $X ; 1 \leqq T \leqq 5 \cdots \cdots 0 \quad 6 \leqq T \leqq 9 \cdots \cdots 1$

$A=0.476 \times 10^{-1}, \quad B=0.1433, \quad C=0.751$,

$\sigma_{A}=0.426 \times 10^{-2}, \quad \sigma_{B}=0.221 \times 10^{-1}$,

$\sigma_{C}=0.1474 \times 10^{-1}, t_{A}=11.12, t_{A}=6.48, \bar{R}^{2}=0.993$

滋賀県については次のと扣り

$$
\begin{array}{r}
D=A T+B X+C \\
X ; 1 \leqq T \leqq 4 \cdots \cdots \cdot 1 \\
5 \leqq T \leqq 9 \cdots \cdots 1
\end{array}
$$

$A=0.617, \quad B=0.1466 \times 10, \quad C=0.636 \times 10$,

$\sigma_{A}=0.584 \times 10^{-1}, \quad \sigma_{B}=0.304, \quad \sigma_{C}=0.1848$,

$t_{A}=10.56, \quad t_{B}=4.83, \quad \bar{R}^{2}=0.991$

以上の予測式に上って昭和 42 年〜 44 年宗での予测を 行なってみたのが表 10 である。な出これ纯罢民 1 人あ たりの値であるから, 県内総需要を求めるには, これに 各県の人口数の予測值を掛けなければならない。
A $\begin{array}{cccccc}\sigma_{A} & B & \sigma_{E} & t_{A} & \bar{R}^{2}\end{array}$

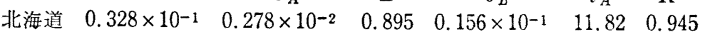

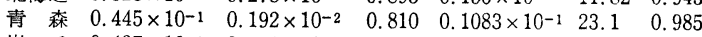


$\begin{array}{llllll}\text { 宮 城 } 0.559 \times 10^{-1} & 0.308 \times 10^{-2} & 0.693 & 0.1731 \times 10^{-1} & 18.16 & 0.976\end{array}$

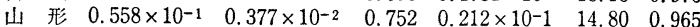

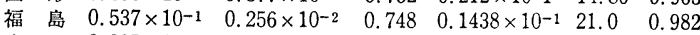

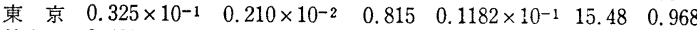
$\begin{array}{lllllll}\text { 神奈川 } & 0.423 \times 10^{-1} & 0.418 \times 10^{-2} & 0.749 & 0.235 \times 10^{-1} & 10.12 & 0.927\end{array}$ 千 葉 $\quad 0.475 \times 10^{-1} \quad 0.371 \times 10^{-2} \quad 0.699 \quad 0.209 \times 10^{-1} \quad 12.78 \quad 0.953$

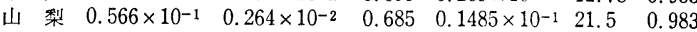

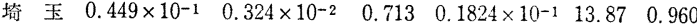

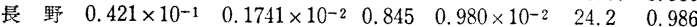
新 $\begin{array}{lllllll}\text { 潟 } & 0.495 \times 10^{-1} & 0.1909 \times 10^{-2} & 0.801 & 0.1074 \times 10^{-1} & 25.9 & 0.988\end{array}$

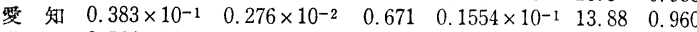

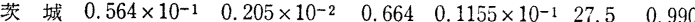

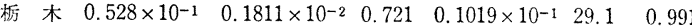

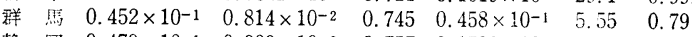


三 重 $\quad 0.319 \times 10^{-1} \quad 0.221 \times 10^{-2} \quad 0.784 \quad 0.1246 \times 10^{-1} \quad 14.42 \quad 0.963$ 岥 阜 $0.320 \times 10^{-1} \quad 0.784 \quad 0.22 \times 100.963$

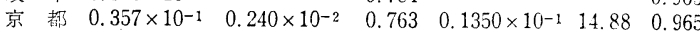



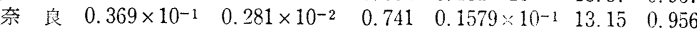

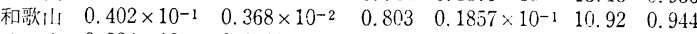
兵 㡷 $0.384 \times 10^{-1} \quad 0.1913 \times 10^{-2} \quad 0.758 \quad 0.1076 \times 10^{-1} \quad 20.1 \quad 0.980$ 石）

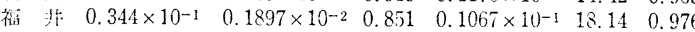



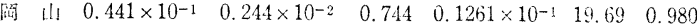
$\begin{array}{lllllll}\text { 広星 } & 0.371 \times 10^{-1} & 0.1844 \times 10^{-2} & 0.860 & 0.1038 \times 10^{-1} & 20.1 & 0.981\end{array}$



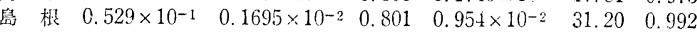

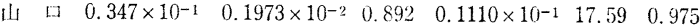

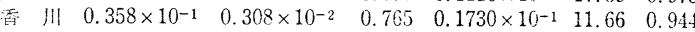

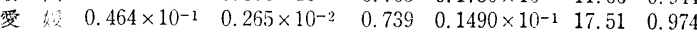

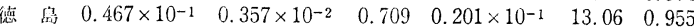

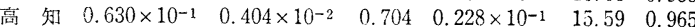
$\begin{array}{lllllll}\text { 福 同 } & 0.389 \times 10^{-1} & 0.1747 \times 10^{-2} & 0.817 & 0.983 \times 10^{-2} & 22.3 & 0.984\end{array}$



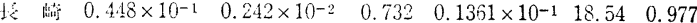
$\begin{array}{lllllll}\text { 紧 本 } 0.422 \times 10^{-1} & 0.207 \times 10^{-2} & 0.662 & 0.1162 \times 10^{-1} & 20.4 & 0.981\end{array}$

\begin{tabular}{|c|c|c|c|c|c|c|c|}
\hline 地域 & 42 年 & 43 年 & 44 作 & 测域 & 42 垈 & $43 x$ & 44 年 \\
\hline 北海道 & 16.7 & 18.1 & 19.5 & 大磁 & 14.5 & 15.7 & 17.1 \\
\hline 箐 菻 & 18.2 & 20.1 & 22.3 & 索坫 & 12.9 & 14.0 & 15.3 \\
\hline 岩 手 & 19.2 & 21.5 & 24.0 & 和级! I & 16.0 & 17.6 & 19.3 \\
\hline 容 城 & 17.8 & 20.3 & 23.1 & 兵州 & 13.9 & 15.2 & 16.5 \\
\hline 秋 田 & 23.5 & 26.2 & 29.3 & 不 川 & 16.6 & 17.8 & 19.1 \\
\hline 山 形 & 20.4 & 23.2 & 26.4 & 䄆 非 & 15.7 & 17.0 & 18.3 \\
\hline 福 易 & 19.3 & 21.8 & 24.7 & 筒 & 18.5 & 19.9 & 21.4 \\
\hline 東 景 & 13.8 & 14.9 & 16.0 & 阔 期 & 15.3 & 17.0 & 18.8 \\
\hline 神尞川 & 14.8 & 16.4 & 18.0 & Lis lis & 17.1 & 18.5 & 20.2 \\
\hline 千 葉 & 14.9 & 16.6 & 18.6 & 取 & 22.7 & 25.7 & 28.9 \\
\hline 山 梨 & 17.8 & 20.3 & 23.2 & 品 樹 & 21.4 & 24.1 & 27.3 \\
\hline 㺃 王 & 14.5 & 16.1 & 18.0 & 山 마 & 17.4 & 18.8 & 20.4 \\
\hline 長 野 & 18.4 & 20.3 & 22.4 & 暪 川 & 13.3 & 14.4 & 15.7 \\
\hline 新 潟 & 19.8 & 22.2 & 24.9 & 無 如 & 16.0 & 17.8 & 19.8 \\
\hline 愛 知 & 11.3 & 12.4 & 13.5 & 德 & 15.0 & 16.7 & 18. ô \\
\hline 茨 城 & 16.9 & 19.2 & 22.2 & 简 知 & 21.6 & 25.0 & 28.0 \\
\hline 杤 木 & 17.7 & 20.0 & 22.6 & 福 㳉 & 17.2 & 18.8 & 20.6 \\
\hline 群 憵 & 13.2 & 17.5 & 19.4 & 伀 分 & 19.7 & 22.0 & 24.7 \\
\hline 静＼cjkstart网 & 15.4 & 17.0 & 18.8 & 抹 崳 & 15.1 & 16.8 & 18.6 \\
\hline 三 璉 & 12.7 & 13.7 & 14.7 & 熊 朴 & 12.1 & 13.4 & 14.7 \\
\hline 㥀 & 12.7 & 13.7 & 14.7 & 大 分 & 14.3 & 15.8 & 17.4 \\
\hline 浯 & 14.0 & 14.6 & 15.2 & 宽 崎 & - & 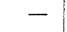 & - \\
\hline T t & 13.2 & 14.3 & 15.5 & 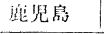 & - & -1 & - \\
\hline
\end{tabular}

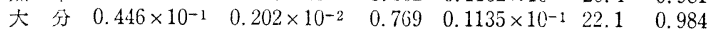

表 10 都道府県 1 人あたり渻酒消奖玉の子测值 $($ 筆红；l) 